\title{
Electricity Access Threshold for Meeting Non-Energy SDG Targets
}

\author{
Robert Brecha ${ }^{1}$
}

\begin{abstract}
Access to sufficient amounts of energy is a prerequisite for development of human well-being. Analysis presented in this paper shows that multiple sustainable development targets are linked to per capita access to electricity in particular and demonstrate a threshold behavior below which sustainable development targets have not been met historically. The present work relates to the broad literature on the Sustainable Development Goals (SDGs), recognizing the interconnectedness of energy access (SDG7) and other development goals. Although targets are provided for each of the 17 goals, not all targets are quantified, leaving room for ambiguity in fulfilling, for example, the goal of "ensuring access to affordable, reliable, sustainable and modern energy for all." The focus of this work is an extension of our previous finding that a per capita societal electricity consumption threshold of about $400 \mathrm{kWh}$ is strongly related to meeting outcomes for health indicators related specifically to SDG targets. In this contribution we further examine this quantitative relationship between electricity access as correlated with education, sanitation, food security and health outcomes, posing the question in the form, "Below what minimum societal per capita access to electricity is a country very unlikely to meet SDG targets?"
\end{abstract}

\section{Introduction}

Energy access plays a key role in economic and human development, as exemplified in Sustainable Development Goal (SDG) 7: "ensure access to affordable, reliable, sustainable and modern energy for all." At the same time, it is recognized that access to energy is not an end in itself, but rather that there are important links between access to sustainable modern energy and the achievement of other SDGs. There is a large literature on both requisite levels of energy access (Krugman and Goldemberg 1983; Goldemberg et al. 1985; Sathaye et al. 2011; S Pachauri et al. 2012; Nussbaumer, Bazilian, and Modi 2012; Bhatia and Angelou 2015; Rao and Pachauri 2017; Pelz, Pachauri, and Groh 2018; Jain and Shahidi 2019), especially at the household level (Shonali Pachauri and Spreng 2002; S. Pachauri et al. 2004; Shonali Pachauri et al. 2013; Groh, Pachauri, and Rao 2016), as well as a growing literature on SDG synergies (and less commonly, mutual barriers) (Collste, Pedercini, and Cornell 2017; Weitz et al. 2017; Taylor et al. 2017; McCollum et al. 2018).

In this paper we go beyond the qualitative linkages between energy access and other SDGs and look at development indicator data for most countries, examining how specific levels of average per capita annual energy (or electricity) consumption is correlated with achieving specific SDG quantitative targets.

\section{Energy Access and Human Development}

The Human Development Index (HDI) is one measure of average quality of 
life for a country (UNDP 2016). Expressed on a scale between 0 and 1, the HDI is a composite index of economic wealth, education, and health indicators. Human Development Index data from the United Nations Development Programme form part of the Human Development Report published each year. Data for both the overall index as well as for the individual components are publicly available (at http://hdr.undp.org/en/content/human-development-index-hdi). For the present work, chosen years for the HDI are matched to the years for which energy data are available, usually 2014. A plot of HDI values vs. final energy consumption per person (IEA 2016) as shown in Fig. 1 results in a characteristic trend toward higher levels of HDI with greater energy consumption, at least for lower levels of HDI. Beyond a certain level (greater than an HDI of about 0.8 and final energy consumption of 50GJ per capita annually), however, increased energy consumption does not correlate with an increase in well-being. The diamonds in Fig. 1 represent a snapshot of HDI values in the year 2014 for 142 countries for which both HDI and final energy data were available. The United Nations Development Programme considered ranges of human development (2014): $<0.55$, low (12\% of world population); 0.55-0.70, medium (37\%); 0.70-0.80, high (31\%); $>0.80$, very high $(20 \%)$.

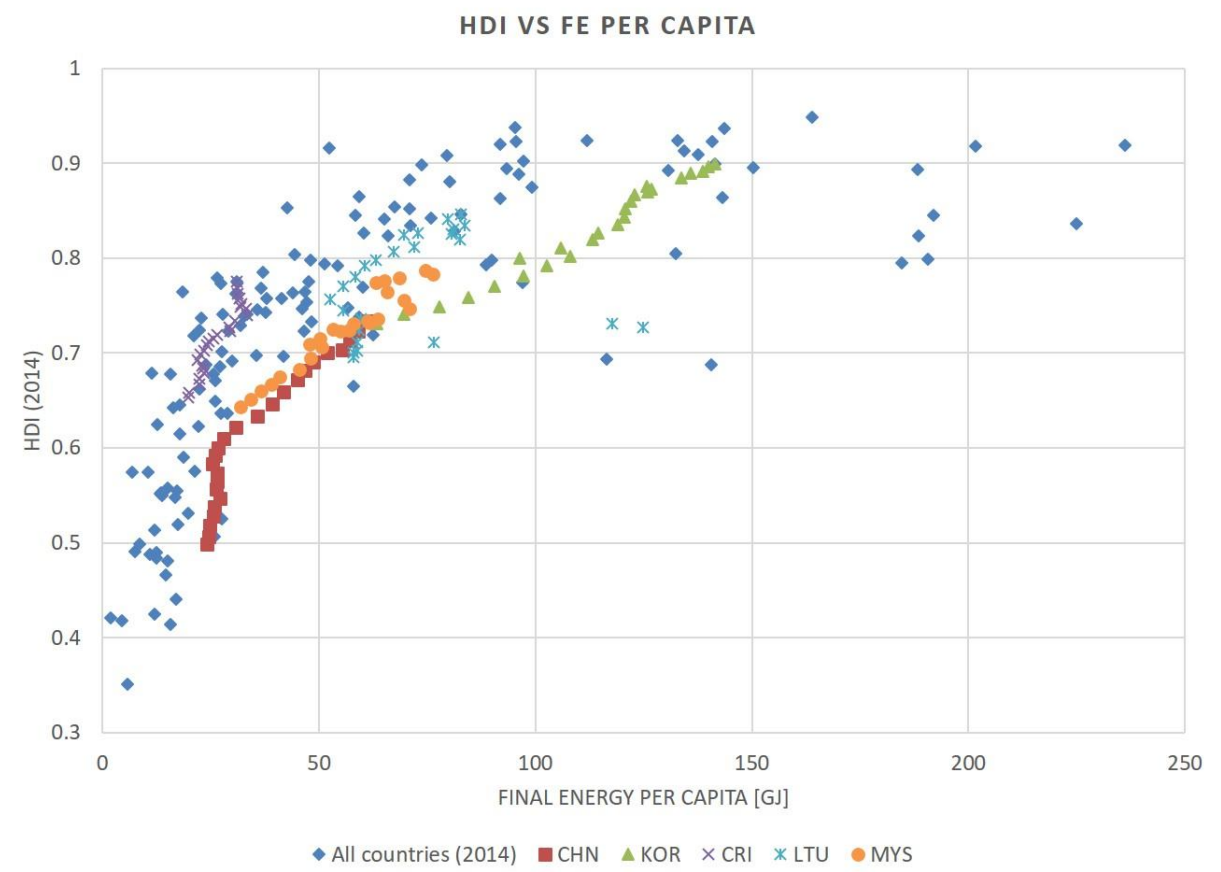

Figure 1 - Human Development Index as a function of per capita final (i.e. useful) energy. The diamonds are a snapshot of all countries with available data in the year 2014. The other series are for selected individual countries in one-year steps from 1990 to 2014. Individual countries are China, Korea, Costa Rica, Lithuania and Malaysia. Sources of data: UN Development Programme, http:// hdr.undp.org/en/content/ buman-development-index-hdi and International Energy Agency, http://wds.iea.org/wds/ReportFolders/ReportFolders.aspx?CS referer=ECCS ChosenLang=en and World Bank, World Data Indicators, http://databank.worldbank.org/data/ reports.aspx? source=world-developmentindicators \# 
The low-energy, low-HDI end of the scale is most crucial, and leads to the framing we use in what follows. No country at a "very high" level of HDI (above 0.8) has an average availability of final energy of less than 40 GJ per person per year' ${ }^{1}$ (In the US, final energy consumption is approximately 200GJ.) Furthermore, we can look at these data to see how several individual countries develop over time (represented by the time series of symbols from 1990-2014), and find that they follow a path that moves through stages represented by the snapshot of countries today, tracking from the lower left toward the upper right of the plot.

\section{HDI and Electricity Consumption}

We further narrow our focus to electricity, as the most modern and flexible of energy sources, and examine individual components of the HDI (GDP, life expectancy, years of schooling). The relationship between the Human Development Index (HDI) and per capita electricity consumption is shown in Fig. 2. Data for 172 countries are shown in Fig. 2a, representing about $97 \%$ of the world's population for which data on both HDI (vertical axis) and per capita electricity consumption (kWh per person per year, horizontal axis) are available for the year 2014². From Fig. 2b, it appears that achieving an HDI of greater than 0.7 is inconsistent with having per capita electrification of less than $1000 \mathrm{kWh}$ annually. This set of countries represents about $42 \%$ of the world's country population. Looking even further (Fig. 2c), countries with greater than $400 \mathrm{kWh}$ per capita are likely to have an HDI $>0.55$, and those with access less than $\sim 400 \mathrm{kWh} /$ capita all have an HDI of $<0.6$ (Fig. $2 \mathrm{~d}$ ). It is these countries that are the focus of this paper. We choose the value of $400 \mathrm{kWh}$ as a marker based not only on this observation of data, but also on previous work we have done looking at achievement of SDG numerical targets for health indicators (Brecha 2019). Approximately $15 \%$ of the world's population lives in countries with access to less than an average of $400 \mathrm{kWh}$ per capita, representing at least one billion people.

\footnotetext{
${ }^{1}$ In energy units, $40 \mathrm{GJ}$ is approximately $11,000 \mathrm{kWh}$, or one "tonne of oil equivalent (toe)". An average power of $1 \mathrm{~kW}$ is equivalent to an annual energy consumption $8760 \mathrm{kWh}$. To the level of precision needed here, we can consider $40 \mathrm{GJ}$ per capita and 1 toe and $1 \mathrm{~kW}$ to all be equivalent expressions for the same level of energy access.

2 Wealthy countries, as represented by the Organization for Economic Cooperation and Development (OECD) have per capita annual electricity consumption of $>5000 \mathrm{kWh}$, with an average of over 8000 $\mathrm{kWh} /$ person/year, with the United States at more than 12,000kWh/person/year (average value including all sectors of the economy)
} 

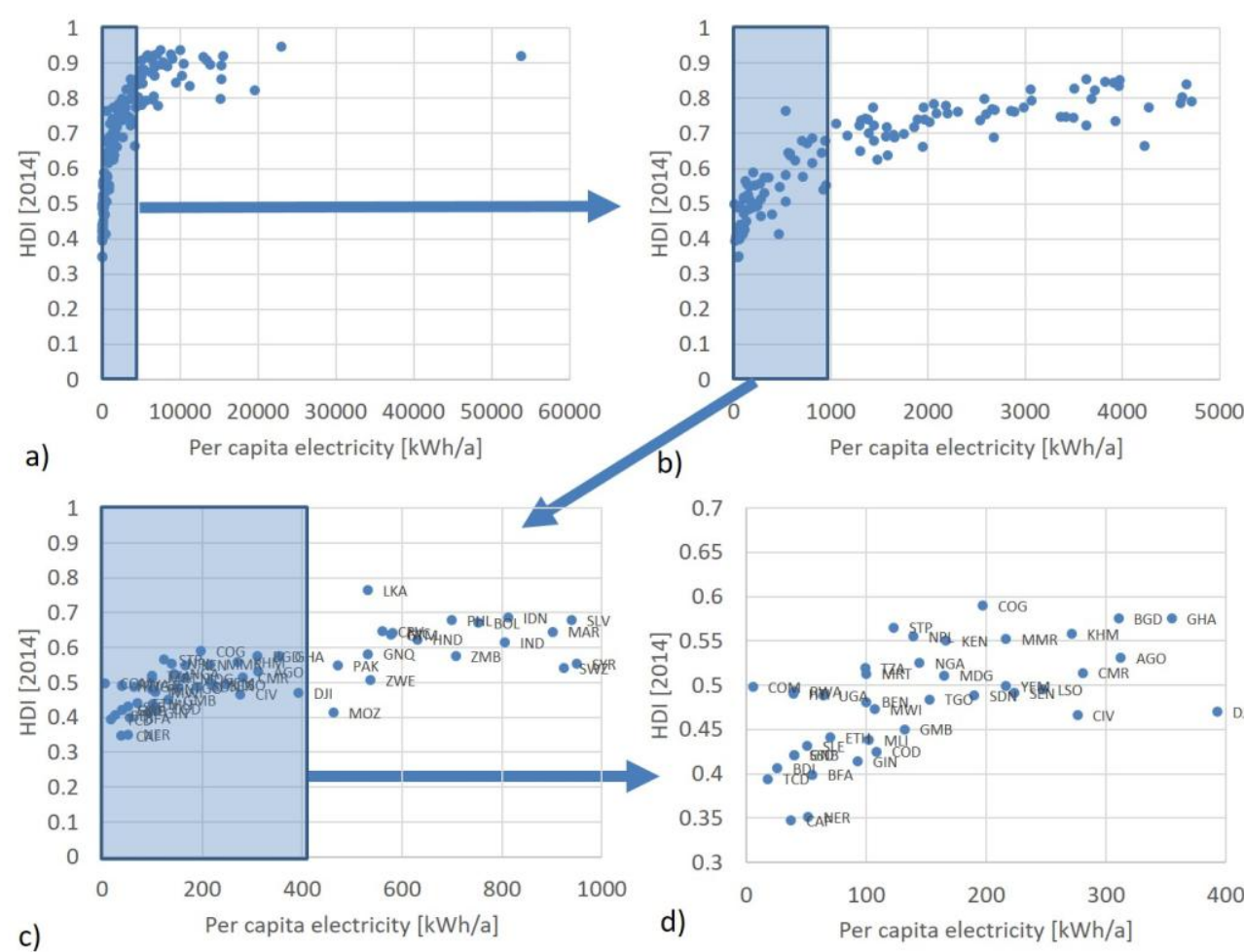

b)

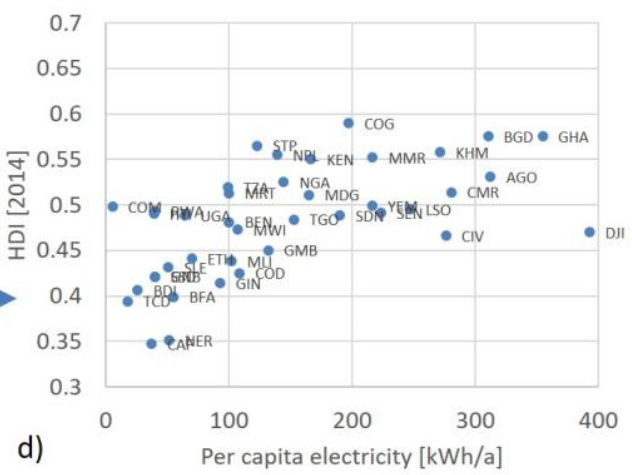

Figure 2 - Human Development Index as a function of per capita electricity consumption in kWh per year $[\mathrm{kWh} / \mathrm{a}]$. Each point represents one country with data from 2014. Source: World Development Indicators, http:/ / databank.worldbank.org/data/ reports.aspx?source=world-development-indicators\# and http:// bdr.undp.org/en/content/ buman-development-index-hdi

\section{Education, Health, Wealth, and Life Expectancy}

One component of the HDI is mean years of schooling. Access to education is also addressed by SDG 4, to "ensure inclusive and quality education for all and promote lifelong learning” (UN General Assembly 2015), with targets involving universal access, literacy and numeracy, and appropriate facilities. Fig. 3a shows histograms for mean years of schooling (UNDP 2016), with different country groups divided by per capita electricity consumption (World Bank 2017). No country with electricity access lower than $400 \mathrm{kWh}$ per capita has more than primary school education levels on average. In contrast, countries with greater than $400 \mathrm{kWh}$ of per capita average annual electricity consumption are very unlikely to average less than nearly eight years of schooling (Education Index of 0.6-0.7). Given that one specific target for SDG 4 is "By 2030, ensure that all girls and boys complete free, equitable and quality primary and secondary education," it appears that only countries with more than at least $400 \mathrm{kWh}$ of per capita annual electricity consumption meet that target. 

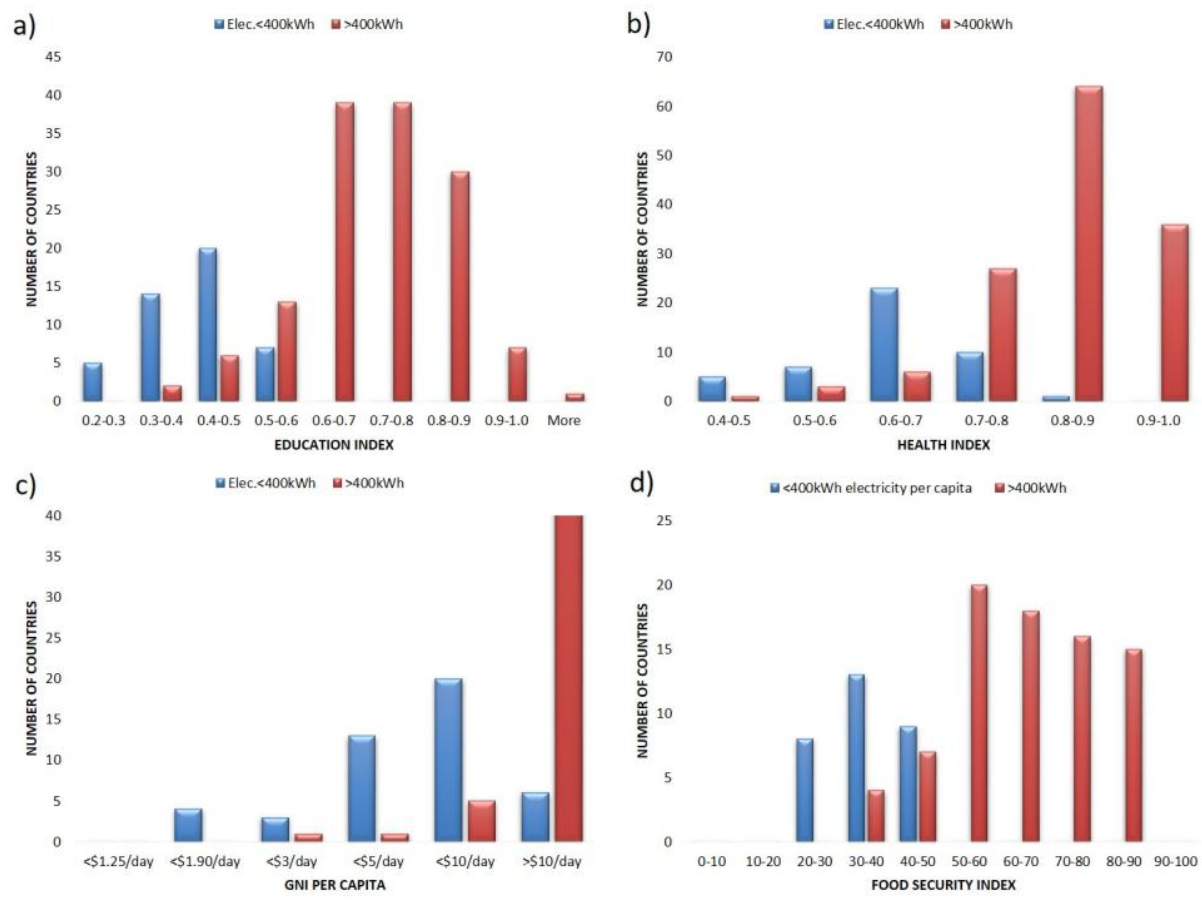

Figure 3 - a) Education index (mean and expected years of schooling) for different electricity consumption ranges. b) Histogram of the number of countries with different ranges of life expectancy at birth. c) Per capita Gross National Income (GNI) for different electricity consumption groups. d) Global Food Security index for 111 countries. Countries are grouped by how much electricity is consumed on average per capita per year. Groups of countries are those with $<400 \mathrm{kWh}$ per capita average annual consumption (blue bars), and those with $>400 \mathrm{kWh}$ (red bars). Data from UNDP, bttp://bdr.undp.org/en/data, for food security, from http:/ / foodsecurityindex.eiu.com/.

In Fig. $3 \mathrm{~b}$ the world is again divided into countries that have, on average, access to either less than or more than $400 \mathrm{kWh} /$ person/year. If a country has access to less than $400 \mathrm{kWh}$ of electricity per person, it is highly likely that the average life expectancy at birth is greater than 70 years. Average life expectancy at birth is between 70-85 years for those with higher electricity access. In addition to being a component of HDI, life expectancy links energy access to SDG3, "Ensure healthy lives and promote well-being for all at all ages." Our previous work has made this linkage more explicit and forms the basis for the threshold electricity consumption level used here. (Brecha 2019)

Fig. $3 \mathrm{c}$ is a histogram of the different electricity-consumption groups, each divided into bins corresponding to different per capita incomes. Of countries with per capita GNI corresponding to less than $\$ 5 /$ day (more than twice the poverty definition of $\$ 1.90 /$ day), $90 \%$ have average per capita electricity consumption under $400 \mathrm{kWh} /$ year. Conversely, of those countries with per capita GNI greater than $\$ 10 /$ day, only $5 \%$ have $<400 \mathrm{kWh} /$ year electricity consumption. The GNI measure also corresponds to an augmented version of SDG1, to "end poverty in all its forms, everywhere" (UN General Assembly 2015). For comparison, Italy has a GNI per capita of $\sim \$ 100 /$ day, the United States about $50 \%$ 
more than that.

As another example, SDG 2 calls for the world to "End hunger, achieve food security and improved nutrition and promote sustainable agriculture," with targets to "By 2030, end hunger and ensure access by all people, in particular the poor and people in vulnerable situations, including infants, to safe, nutritious and sufficient food all year round" and "By 2030, end all forms of malnutrition, including achieving, by 2025, the internationally agreed targets on stunting and wasting in children under 5 years of age, and address the nutritional needs of adolescent girls, pregnant and lactating women and older persons." One way to expressing these targets is in terms of the Global Food Security Index ${ }^{3}$ an aggregate index on a scale of $0-100$, with components of availability, affordability and quality, the familiar pattern from other development indicators appears. We see in Fig. 3d that no country with less than 400kWh per capita electricity consumption achieves a food security index value of $>50$, whereas those countries with higher per capita electricity consumption are very unlikely to have a low food security index (under 50).

\section{Energy Requirements for All Those with Less than $400 \mathrm{kWh}$ per Capita Average Societal Access}

The population in 2015 for those countries with less than 400kWh per capita electricity consumption is 920 million. The UN projects in its "medium variant" scenario an increase in population to 1.6 billion in 2030 for these same countries (UN Dept of Economic and Social Affairs 2017). Countries currently with less than $400 \mathrm{kWh}$ per capita electricity consumption have an average of about $170 \mathrm{kWh}$ per capita, so total electricity consumption for the 920 million people in these countries is 160 billion $\mathrm{kWh}$ (160 TWh or Terrawatt-hours) as shown in Fig. 4 where curve a) is a plot of cumulative electricity consumption as a function of cumulative total population ends at the point (920[million], 160[TWh]). Taking as a target that each of these countries should have an average per capita electricity consumption of 400kWh by 2030 leads to curve b) in Fig. 4, which shows for this simplified example a total consumption of $640 \mathrm{TWh}$, representing a compounded annual growth rate of $9.3 \%$ /year. Curve c) in Fig. 4 is simply the $9.3 \%$ yearly exponential increase in per capita electricity consumption from its current level to the target level in the year 2030, with population instead of time as the abscissa.

The International Energy Agency (IEA) in its 2017 World Energy Outlook Special Report on Energy Access (IEA 2017) focuses mainly on household electricity (and cooking energy) access, while acknowledging the importance of access to modern sources of energy for productive needs such as the services discussed above. The "Energy for All" scenario looks at providing access at the initial level of $250 \mathrm{kWh}$ per rural household (and $500 \mathrm{kWh}$ for urban households) with a gradual increase thereafter, such that universal access is achieved by 2030. Compared to the baseline "New Policies Scenario" the more ambitious scenario results in additional demand of 119 TWh of electricity demand by 2030 , at an additional cumulative investment cost of $\$ 391$ billion, or an average of $\$ 28$ billion per year. The latter represents $1.7 \%$ of annual global energy

\footnotetext{
${ }^{3}$ http:/ / foodsecurityindex.eiu.com/
} 
system investments. (IEA 2017)

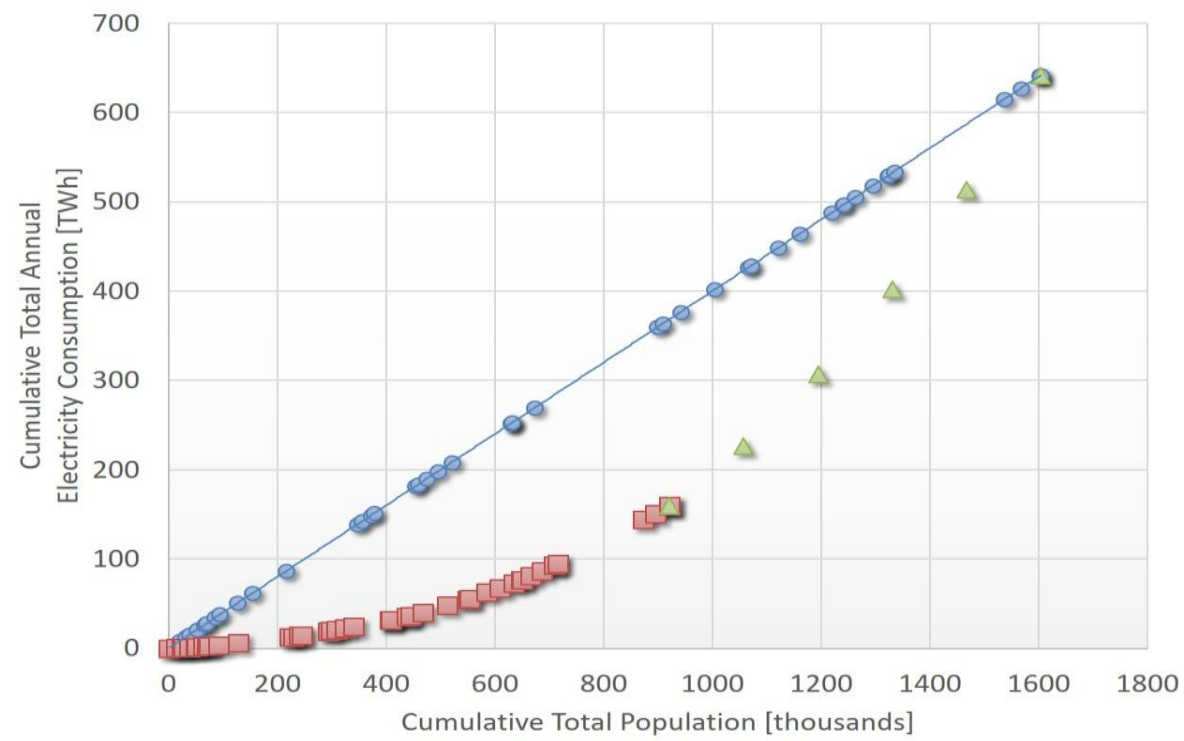

Figure 4 - Cumulative electricity consumption as a function of cumulative population for all countries with $<400 \mathrm{kWh}$ per capita average annual consumption.

Furthermore, the additional access to electricity for 674 million people by 2030 compared to the New Policy Scenario implies approximately $175 \mathrm{kWh}$ per capita per year access. For the example we have given above, and current consumption levels across the energy-poor countries, approximately two times as much would be needed to satisfy the goal of reaching $400 \mathrm{kWh}$ per capita electricity availability. The IEA estimates from their modeling that additional investments of $\$ 391$ billion are necessary for their goal; a rough extrapolation would double this to $\$ 800$ billion in cumulative investments by 2030 , or $\sim$ \$60 billion per year, representing approximately $3.5 \%$ of global investment in energy systems. (IEA 2017)

\section{Discussion}

Countries with average per capita electricity consumption of less than 400kWh per year have uniformly poor human development indicators, and few if any at this level of consumption meet SDG targets for health, wealth, education, sanitation or food security. On the other hand, this can be expressed by stating, from the same data, that there are relatively few countries with average electricity access of $>400 \mathrm{kWh}$ per capita that have an average number of years of education less than eight, or life expectancy at birth of less than 70 years, or high mortality rates for women, infants or young children. For reference, $400 \mathrm{kWh}$ per capita is approximately one-fifth the level of electricity use in the US in 1950; the SDG indicators for life expectancy and average educational attainment are roughly those for the US at that time as well. If it is possible to achieve 
society-wide targets at lower levels of electricity consumption, then it must be shown how that is to be accomplished. For example, efficient appliances and lighting may contribute to lowering the bar for energy-related indicators. It is also clear that energy access must be planned and implemented in a systemic fashion so that household and productive uses are addressed effectively; in that sense, it is also important to consider SDGs that support the goals and targets discussed here: SDG 9 - Industry, Innovation and Infrastructure; SDG 16 - Peace, Justice and Strong Institutions; and SDG 17 Partnership for the Goals.

One possible objection to this analysis is that electricity access has been chosen as the independent variable, but that other variables could have been chosen. In other words, energy access might be just a proxy for "wealth" or GNI/capita. In fact, the two are closely related. Interestingly, the threshold behavior identified in our previous work (Brecha 2019), from which we derive the per capita consumption level of approximately $400 \mathrm{kWh}$ used in the present analysis, is not as evident as a function of GDP as it is in terms of electricity access. Additionally, it is possible to construct causal chains showing that it truly is energy access that is a key to achieving these (and possibly other) SDGs, and not just increase in wealth. Although there is the potential for conflicts between SDGs (Stechow et al. 2016; McCollum et al. 2018; Nilsson, Griggs, and Visbeck 2016; Weitz et al. 2017) clear connections have been made by others between access to electricity in support of achieving other goals (McCollum et al. 2018).

In Table 1 we compile linkages between the SDGs considered in this paper and access to electricity (and more broadly, other modern energy sources). The examples here are mainly based on McCollum et al. In that work, there are also potential negative aspects of energy access, depending on the particular sources used; here we are concerned mainly with the implications for having access to enough electricity (and at the relatively low levels correlated with achieving SDG targets).

Table 1 - Summary of key synergies between access to electricity and other SDGs, focusing on the causal connections

\begin{tabular}{|l|l|l|l|l|}
\hline SDG 1 - Poverty & $\begin{array}{l}\text { SDG 2 - } \\
\text { Hunger }\end{array}$ & SDG 3 - Health & $\begin{array}{l}\text { SDG 4 - } \\
\text { Education }\end{array}$ & $\begin{array}{l}\text { SDG 6 - Water } \\
\text { and Sanitation }\end{array}$ \\
\hline $\begin{array}{l}\text { Modern energy } \\
\text { (electricity) } \\
\text { fundamental for } \\
\text { development }\end{array}$ & $\begin{array}{l}\text { Energy access } \\
\text { can help reduce } \\
\text { post-harvest } \\
\text { losses }\end{array}$ & $\begin{array}{l}\text { Electricity allows } \\
\text { storage of } \\
\text { medicine and } \\
\text { vaccines }\end{array}$ & $\begin{array}{l}\text { Lighting allows } \\
\text { more opportunity } \\
\text { for studying at } \\
\text { home }\end{array}$ & $\begin{array}{l}\text { Electricity can } \\
\text { allow access to } \\
\text { pumping for safer } \\
\text { drinking water }\end{array}$ \\
\hline $\begin{array}{l}\text { Access to electricity } \\
\text { (and other modern } \\
\text { energy) frees up } \\
\text { time and other } \\
\text { resources }\end{array}$ & $\begin{array}{l}\text { Food } \\
\text { preservation } \\
\text { improved by } \\
\text { access to } \\
\text { electricity }\end{array}$ & $\begin{array}{l}\text { Improved lighting } \\
\text { and equipment } \\
\text { power in clinics }\end{array}$ & $\begin{array}{l}\text { Electricity in } \\
\text { schools provides } \\
\text { better lighting and } \\
\text { information } \\
\text { technology access }\end{array}$ & \begin{tabular}{l}
$\begin{array}{l}\text { Electricity access } \\
\text { will allow for } \\
\text { desalination to } \\
\text { enhance scarce } \\
\text { water resources }\end{array}$ \\
\hline Power needed for \\
water treatment
\end{tabular} \\
\hline $\begin{array}{l}\text { Better food } \\
\text { preservation } \\
\text { contributes to } \\
\text { better health } \\
\text { outcomes }\end{array}$ & & \\
\hline
\end{tabular}


In conclusion, access to modern energy systems, and primarily to electricity, is strongly linked to being able to achieve targets set for many Sustainable Development Goals. Although gains in efficiency in the future as well as some geographical and countryspecific factors may affect the exact level of consumption, we have shown here that below a societal level of $400 \mathrm{kWh}$ per capita annually, very few countries have been able to meet SDG targets. Furthermore, even this relatively meager amount of electricity is higher than what is projected for 2030 in international modeling efforts. Therefore, either higher levels of electricity access must be assumed for models to be consistent with the SDGs, or else it is necessary to demonstrate how the SDGs can be achieved without that level of access to modern energy.

\section{Appendix: Data Sources}

Human Development Index data are from the United Nations Development Programme as part of the Human Development Report published each years. Data for both the overall index as well as for the individual components are available at http://hdr.undp.org/en/content/human-development-index-hdi. For the present work, chosen years for the HDI are matched to the years for which energy data are available, usually 2014.

Specific data sets used are:

\begin{tabular}{|l|l|l|}
\hline Human Development Index (HDI) & $\underline{\text { http://hdr.undp.org/en/indicators/137506 }}$ & S1, S2 \\
\hline Life expectancy at birth & $\underline{\text { http://hdr.undp.org/en/indicators/69206 }}$ & $\mathrm{S} 4$ \\
\hline Mean years of schooling & http://hdr.undp.org/en/indicators/103006 & 1 \\
\hline Gross national income (GNI) per capita & http://hdr.undp.org/en/indicators/141706 & \\
\hline Final energy use [GJ] & IEA Energy Balances & $\mathrm{S} 1$ \\
\hline
\end{tabular}

Data for other indicators are taken from the World Bank database of World Development Indicators (WDI) that can be found at https://data.worldbank.org/indicator. Specific indicators used here are:

\begin{tabular}{|l|l|l|}
\hline Indicator name & Indicator code & Fig. \\
\hline Electric power consumption (kWh per capita) & EG.USE.ELEC.KH.PC & S2 \\
\hline Energy use (kg of oil equivalent per capita) & EG.USE.PCAP.KG.OE & \\
\hline GDP per capita, PPP (constant 2011 international \$) & NY.GDP.PCAP.PP.KD & S3 \\
\hline Maternal mortality ratio (modeled estimate, per 100,000 live births) & SH.STA.MMRT & 2a \\
\hline Mortality rate, under-5 (per 1,000 live births) & SH.DYN.MORT & 2c \\
\hline Mortality rate, neonatal (per 1,000 live births) & SH.DYN.NMRT & 2b \\
\hline Life expectancy at birth, total (years) & SP.DYN.LE00.IN & \\
\hline Access to clean fuels and technologies for cooking (\% of population) & EG.CFT.ACCS.ZS & \\
\hline Improved sanitation facilities (\% of population with access) & SH.STA.ACSN & 2d \\
\hline Population, total & SP.POP.TOTL & \\
\hline
\end{tabular}

Population data, both current and projected increases, are taken from the United Nations World Population Prospects 2015 update, POP/DB/WPP/Rev.2015/POP/F01-1. 
For many African countries, the WDI database does not include per capita electricity consumption. To fill in these gaps, the United Nations Environment Programme Atlas of Africa Energy Resources was used (UNEP 2017) as were data from the United States Energy Information Administration (https://www.eia.gov/ ).

\section{References}

Bhatia, M, and N Angelou. 2015. "Beyond Connections - Energy Access Redefined." Technical report $008 / 15$.

Brecha, R.J. 2019. "Threshold Electricity Consumption Enables Multiple Sustainable Development Goals.” Submitted to Nature Sustainability.

Collste, David, Matteo Pedercini, and Sarah E. Cornell. 2017. "Policy Coherence to Achieve the SDGs: Using Integrated Simulation Models to Assess Effective Policies." Sustainability Science, July. https://doi.org/10.1007/s11625-017-0457-x.

Goldemberg, T.B. Johansson, A.K.N. Reddy, and R Williams. 1985. "Basic Needs and Much More with One Kilowatt per Capita." Ambio, 1985.

Groh, Sebastian, Shonali Pachauri, and Narasimha D. Rao. 2016. "What Are We Measuring? An Empirical Analysis of Household Electricity Access Metrics in Rural Bangladesh." Energy for Sustainable Development 30 (February): 21-31. https://doi.org/10.1016/j.esd.2015.10.007.

IEA. 2012. Energy Balances of Non-OECD Countries - 2012 Edition. International Energy Agency, Paris. . 2017. "World Energy Outlook Special Report on Energy Access." International Energy Agency.

Jain, Abhishek, and Tauseef Shahidi. 2019. "Guiding Action: A User Centric Approach to Define, Measure and Manage Electricity Acces." Economics of Energy \& Environmental Policy 8 (1): 19-32.

Krugman, H., and J Goldemberg. 1983. "The Energy Cost of Satisfying Basic Human Needs." Technological Forecasting and Social Change, 1983.

McCollum, David L, Luis Gomez Echeverri, Sebastian Busch, Shonali Pachauri, Simon Parkinson, Joeri Rogelj, Volker Krey, et al. 2018. "Connecting the Sustainable Development Goals by Their Energy Inter-Linkages.” Environmental Research Letters 13 (3): 033006. https://doi.org/10.1088/1748-9326/aaafe3.

Nilsson, Måns, Dave Griggs, and Martin Visbeck. 2016. "Map the Interactions between Sustainable Development Goals." Nature 534 (June): 320-22.

Nussbaumer, Patrick, Morgan Bazilian, and Vijay Modi. 2012. "Measuring Energy Poverty: Focusing on What Matters." Renewable and Sustainable Energy Reviews 16 (1): 231-43. https://doi.org/10.1016/j.rser.2011.07.150.

Pachauri, S, A Brew-Hammond, Douglas F. Barnes, D.H. Bouille, S Gitonga, V Modi, G Prasad, A Rath, and H Zerriffi. 2012. "Chap. 19 - Energy Access for Development." In Global Energy AssessmentToward a Sustainable Future, 1401-58. Cambridge: Cambridge University Press and International Institute for Applied Systems Analysis.

Pachauri, S., A. Mueller, A. Kemmler, and D. Spreng. 2004. "On Measuring Energy Poverty in Indian Households." World Development $32 \quad$ (12): 2083-2104. https://doi.org/10.1016/j.worlddev.2004.08.005.

Pachauri, Shonali, Bas J van Ruijven, Yu Nagai, Keywan Riahi, Detlef P van Vuuren, Abeeku BrewHammond, and Nebojsa Nakicenovic. 2013. "Pathways to Achieve Universal Household Access to Modern Energy by 2030." Environmental Research Letters 8 (2): 024015. https://doi.org/10.1088/1748-9326/8/2/024015.

Pachauri, Shonali, and Daniel Spreng. 2002. "Direct and Indirect Energy Requirements of Households in India." Energy Policy 30 (6): 511-23.

Pelz, Setu, Shonali Pachauri, and Sebastian Groh. 2018. "A Critical Review of Modern Approaches for Multidimensional Energy Poverty Measurement." Wiley Interdisciplinary Reviews: Energy and Environment 7 (6): e304. https://doi.org/10.1002/wene.304.

Rao, Narasimha D, and Shonali Pachauri. 2017. "Energy Access and Living Standards: Some Observations on Recent Trends.” Environmental Research Letters 12 (2): 025011. https://doi.org/10.1088/17489326/aa5b0d. 
Sathaye, Jayant, Oswaldo Lucon, Atiq Rahman, John Christensen, Fatima Denton, Junichi Fujino, Garvin Heath, et al. 2011. "Renewable Energy in the Context of Sustainable Development." In IPCC Special Report on Renewable Energy Sources and Climate Change Mitigation [O. Edenhofer, R. Pichs-Madruga, Y. Sokona, K. Seyboth, P. Matschoss, S. Kadner, T. Zwickel, P. Eickemeier, G. Hansen, S. Schlömer, C.von Stechow (Eds)]. Cambridge, UK, and New York, NY, USA: Cambridge University Press. https://ipcc.ch/pdf/special-

reports/srren/Chapter $\% 209 \% 20$ Renewable $\% 20$ Energy $\% 20$ in $\% 20$ the $\% 20$ Context $\% 20$ of $\% 20$ Sust ainable\%20Development.pdf.

Stechow, Christoph von, Jan C. Minx, Keywan Riahi, Jessica Jewell, David L. McCollum, Max W. Callaghan, Christoph Bertram, Gunnar Luderer, and Giovanni Baiocchi. 2016. "2 ${ }^{\circ} \mathrm{C}$ and SDGs: United They Stand, Divided They Fall?" Environmental Research Letters 11 (3): 034022. https://doi.org/10.1088/1748-9326/11/3/034022.

Taylor, Peter G., Kathleen Abdalla, Roberta Quadrelli, and Ivan Vera. 2017. "Better Energy Indicators for Sustainable Development.” Nature Energy 2 (8): 17117. https://doi.org/10.1038/nenergy.2017.117.

UN Dept of Economic and Social Affairs. 2017. "World Population Prospects 2017." 2017. https://esa.un.org/unpd/wpp/.

UN General Assembly. 2015. Transforming Our World: The 2030 Agenda for Sustainable Development. https: $/ /$ www.google.com $/$ url? sa $=t \& r c t=j \& q=\& e s r c=s \&$ source $=$ web\&cd $=2 \& c a d=$ rja\&uact $=8 \& \mathrm{v}$ ed=0ahUKEwjZ-7PBusnRAhXEyyYKHakDAKcQFggsMAE\&url=http $\% 3 \mathrm{~A} \% 2 \mathrm{~F} \% 2 \mathrm{~F}$ www.un.org $\% 2$ Fsustainabledevelopment $\% 2$ Fdevelopment-agenda $\% 2 \mathrm{~F} \&$ usg $=\mathrm{AFQjCNHsy}$ UhLC3HVpbu5w-C-YGkRRxPc2Q\&sig2=kJReLwsoSiwm_A94lwWYRw.

UNDP, ed. 2016. Human Development for Everyone. Human Development Report 2016. New York, NY: United Nations Development Programme.

UNEP. 2017. Atlas of Africa Energy Resources. Nairobi, Kenya: United Nations Environment Programme. http://hdl.handle.net/20.500.11822/20476.

Weitz, Nina, Henrik Carlsen, Måns Nilsson, and Kristian Skånberg. 2017. "Towards Systemic and Contextual Priority Setting for Implementing the 2030 Agenda." Sustainability Science, September. https://doi.org/10.1007/s11625-017-0470-0.

World Bank. 2017. "World Development Indicators." Database. World Development Indicators. 2017. https://data.worldbank.org/data-catalog/world-development-indicators. 